\title{
Analisis Data Well Log (Porositas, Saturasi Air, dan Permeabilitas) untuk menentukan Zona Hidrokarbon, Studi Kasus: Lapangan "ITS" Daerah Cekungan Jawa Barat Utara
}

\author{
Deni Irawan dan Widya Utama* \\ Laboratorium Geofisika, Juruan Fisika, FMIPA \\ Institut Teknologi Sepuluh Nopember \\ Kampus ITS Sukolilo, Surabaya 60111 \\ Totok Parafianto \\ PT. Pertamina, Unit EP Regional Jawa
}

Intisari

\begin{abstract}
Data log sumur dipakai antara lain untuk analisa penyebaran cadangan hidrokarbon dan analisa produksi hidrokarbon tentu saja terintegrasi dengan data seismik, yang menunjang upaya penentuan arah eksplorasi selanjutnya dan produksi pada sumur tersebut. Dalam kajian ini, dilakukan penentuan zona yang terisi hidrokarbon pada lapangan "ITS" di cekungan Jawa Barat sebelah Utara. Data yang digunakan adalah data $\log$ GR, $\log \mathrm{SP}, \log$ resistivitas, log neutron, $\log$ densitas, dan data master log. Penetuan kondisi litologi pada zona interest dilakukan dengan menggunakan data master $\log$ dan metode crossplot NPHI-RHOB. Perhitungan nilai porositas effektif dilakukan melalui integrasi dari analisa data $\log$ densitas, $\log$ neutron, dan $\log$ GR. Nilai resistivitas air (Rw) ditentukan melalui metode Rwa dan saturasi air dengan menggunakan persamaan Archie, untuk memperoleh nilai saturasi air Sw. Melalui persamaan Tixier dengan asumsi Swirr-Sw dapat ditentukan nilai permeabilitas lapisan, yang dapat dibuat peta-peta: top struktur, porositas, saturasi air, dan permeabilitas. Dari hasil analisis data didapatkan nilai porositas tertinggi $17,57 \%$ pada sumur ITS-24, saturasi air terendah 32,84 \% pada sumur ITS-05, permeabilitas tertinggi 90955,1 md dan tebal netpay tertinggi 56 meter pada sumur ITS-06.
\end{abstract}

KATA KUNCI: $\log$ analisis, porositas, saturasi air, permeabilitas,netpay

\section{PENDAHULUAN}

Meningkatnya kebutuhan industri akan sumber energi dan semakin berkurangnya cadangan minyak bumi yang tersedia, telah mendorong perusahaan minyak dan gas untuk menemukan cadangan baru ataupun mengelola sumur-sumur tua (brown pits) untuk menjaga kesetaraan supply and demand.

Langkah eksplorasi minyak dan gas bumi (migas) saat ini menjadi semakin kompleks, mulai dari kajian awal geologi dalam skala regional hingga kajian rinci skala mikro berdasarkan data well-log (sumur bor) dalam upaya mengungkap kondisi rinci dari sebuah petroleum system yang ditemukan.

Well Logging merupakan metode pengukuran parameterparameter fisika, dalam lubang bor, yang bervariasi terhadap kedalaman sumur. Hasil analisis data $\log$ sumur dapat digunakan untuk mengetahui karakteristik reservoar (segi porositas, saturasi air, dan permeabiltas) yang digunakan antara lain untuk menentukan arah eksplorasi dan produksi selanjutnya.

Tujuan dari penelitian ini adalah menganalisis data $\log$

*E-MAIL: widya@physics.its.ac.id

(c) Jurusan Fisika FMIPA ITS sumur lapangan "ITS" cekungan Jawa Barat sebelah Utara untuk menetukan interval zona hidrokarbon, porositas, saturasi air, permeabilitas, dan membuat peta kontur top struktur, peta kontur porositas, peta kontur saturasi air.

\section{DATA PENELITIAN}

Data yang digunakan antara lain:

1. Data Primer, yang berupa data: $\log$ GR,Log SP, $\log r e-$ sistivity, $\log$ neutron, dan $\log$ densitas pada sumur ITS05, ITS-06, ITS-21, ITS-24, ITS-25, ITS-26, ITS-28, dan ITS-29 di lapangan "ITS" cekungan Jawa Barat sebelah Utara

2. Data Sekunder :

- Kolom Stratigafi Cekungan Jawa Barat Utara

- Data master log (Rate Of Penetration, Mud Log, Cuting Decription) sumur ITS-25, ITS-28, ITS29 pada Lapangan "ITS". 


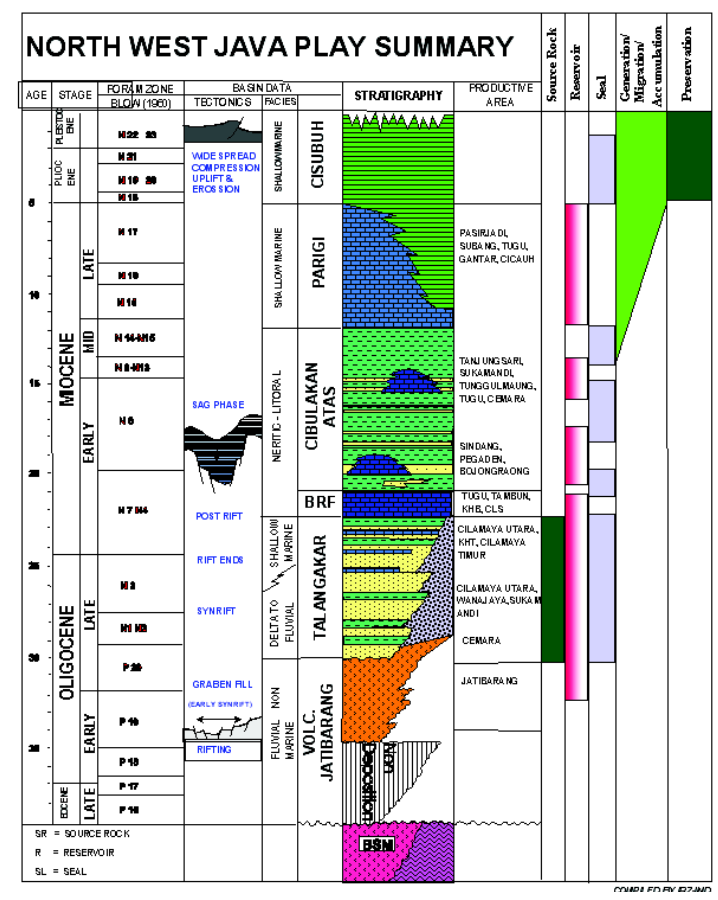

Gambar 1: Kolom stratigafi cekungan Jawa Barat, bagian Utara

\section{METODOLOGI DAN ANALISIS DATA}

Pengolahan data tersebut meliputi beberapa langkah:

1. Identifikasi Zona Permeable

Data $\log$ yang digunakan untuk mengidentifikasi zona permeable dan impermeable adalah data $\log$ GR. Respon GR yang rendah mengindikasikan bahwa pada lapisan tersebut merupakan lapisan yang permeable, sedangkan respon GR yang tinggi mengindikasikan bahwa pada lapisan tersebut merupakan lapisan yang impermeable. Data dari Log GR dipadukan dengan data dari $\log$ SP. Data log GR dipakai untuk menentukan volume shale, lihat Pers. 1. Untuk lapisan yang permeable $\log$ SP menunjukkan defleksi. Arah defleksi dari $\log$ SP tergantung dari nilai Rmf dan Rw pada lapisan tersebut.

$$
V_{\text {Shale }}=\frac{G R_{L o g}-G R_{M i n}}{G R_{M a x}-G R_{M i n}}
$$

2. Identifikasi Zona Hidrokarbon

Setelah diketahui lapisan mana yang merupakan reservoar, selanjutnya dicari lapisan mana yang terisi hidrokarbon. Data log yang digunakan unttuk mengidentifikasikan reservoar yang mengandung hidrokarbon adalah data $\log$ resistivitas, densitas, dan neutron. Untuk lapisan yang terisi hidrokarbon, $\log$ resistivitas menunjukkan respon yang tinggi, dan ada separasi positif antara $\log$ neutron dan densitas, sedangkan untuk lapisan yang mengandung air, $\log$ resistivitas menunjukkan respon yang rendah serta antara $\log$ densitas

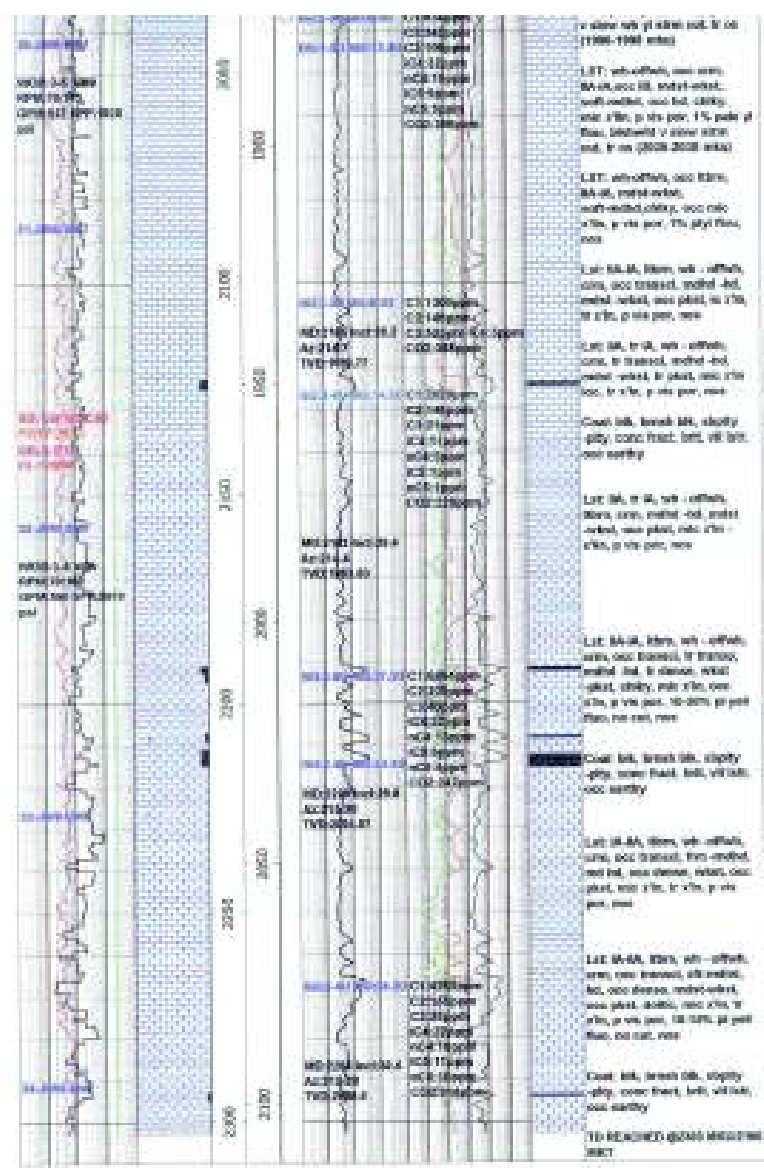

Master Log, ITS-28

Gambar 2: Data master log sumur ITS-28

dan neutron berhimpitan ataupun menunjukkan separasi negatif.

3. Pemisahan Zona Minyak dan Gas

Setelah diketahui lapisan mana yang mengandung hidrokarbon, selanjutnya diidentifikasi jenis hidrokarbon yang mengisi lapisan tersebut. Secara kualitatif data $\log$ yang digunakan untuk mengidentifikasi jenis hidrokarbon adalah data $\log$ densitas, dan neutron. Untuk membedakan lapisan yang terisi gas dan minyak, digunakan separasi positif antara $\log$ densitas dan neutron. Untuk gas menunjukkan respon resistivitas yang lebih tinggi, dan separasi positif log densitas-neutron yang lebih besar daripada minyak. Secara kuantitatif nilai $\mathrm{Sw}<25 \%$ dianggap sebagai gas, $25 \%>\mathrm{Sw}<$ $75 \%$ dianggap minyak, $\mathrm{Sw}>75 \%$ dianggap sebagai air.

\section{Interpretasi Litologi}

Data-data yang digunakan berupa perpaduan dari data log (Crossplot NPHI-RHOB), dan cutting description. Interpretasi ini dilakukan untuk mengetahui jenis litologi reservoar pada setiap sumur. 


\section{Menghitung Porositas}

Data log yang digunakan untuk menghitung porositas adalah perpaduan antara data $\log$ densitas dan neutron. Nilai porositas dari $\log$ densitas $\left(\phi_{d}\right)$ ditentukan dengan menggunakan Pers. 2. Sedangkan untuk log neutron langsung menunjukkan nilai porositas $\left(\phi_{n}\right)$ batuan dengan skala matrik batu gamping, Pers. 3 dan 4 , berikut ini:

$$
\begin{aligned}
\phi_{D} & =\frac{\rho_{m a}-\rho_{b}}{\rho_{m a}-\rho_{f}} \\
\phi_{D C} & =\phi_{D}-\left(V_{S H} \times \phi_{D S H}\right) \\
\phi_{N C} & =\phi_{D}-\left(V_{S H} \times \phi_{N S H}\right)
\end{aligned}
$$

Nilai $\phi_{d s h}$ didapatkan dari nilai porositas dari densitas $\left(\phi_{d}\right)$ pada lapisan lempung. Nilai $\phi_{n s h}$ didapatkan dari $\log$ neutron pada lapisan lempung, Volume shale $\left(\mathrm{V}_{S H}\right)$ dicari dengan menggunakan Pers. 1. Nilai porositas efektif $\left(\phi_{e f f}\right)$ didapatkan dengan persamaan :

$$
\phi_{e f f}=\frac{\phi_{D C}+\phi_{N C}}{2}
$$

6. Menghitung Resistivitas Rw

Nilai Rw didapatkan dengan mencari lapisan reservoar yang terisi penuh dengan air $(\mathrm{Sw}=1)$.Sehingga dengan menganggap nilai $\mathrm{a}=1, \mathrm{~m}=2, \mathrm{n}=2$, maka Pers. 7 menjadi :

$$
R w=\phi R t
$$

Lapisan yang terisi penuh dengan air ditandai dengan rendahnya respon log resistivitas dan berhimpitnya kurva $\log$ neutron dan kurva $\log$ densitas.

7. Menghitung Saturasi Sw

Nilai Rw dihitung dengan menggunakan Pers. 6, dan porositas efektif yang didapatkan dari Pers. 5, dengan menganggap nilai $\mathrm{a}=1, \mathrm{~m}=2, \mathrm{n}=2$.

$$
S w=\frac{a}{\phi_{e f f}} \sqrt{\frac{R w}{R t}}
$$

8. Menghitung Permeabilitas

Nilai permeabilitas dihitung dengan menggunakan Pers. 8, dengan menggunakan nilai Swirr $=\mathrm{Sw}$, dan porositas efektif yang didapatkan dari Pers. 5.

$$
K=\left(\frac{250 \phi_{e f f}^{3}}{S_{w i r r}}\right)^{2}
$$

\section{PENGOLAHAN DATA DAN HASIL-HASILNYA}

Pada penelitian ini digunakan integrasi data log GR dan SP untuk mengetahui batas atas dan bawah zona yang memiliki permeabilitas dan merupakan reservoar. Pada zona yang memiliki permeabiltas ditunjukkan dengan adanya depleksi pada kurva $\log$ SP dan pada kurva $\log$ GR menunjukkan respon yang rendah. Hal ini dikarenakan pada zona yang memiliki permeabilitas yang tinggi unsur-unsur radioactive alami tidak terkosentrasi pada zona tersebut melainkan terkosentrasi pada zona yang tidak memiliki permeabilitas ataupun permeabilitasnya kecil yang identik dengan zona lempung ataupun serpih.

Setelah diketahui zona yang memiliki permeabilitas dan merupakan reservoar hidrokarbon maka dilakukan analisis selanjutnya dengan menggunakan $\log$ resistivitas. Pada $\log$ resistivitas jika pada ketiga kurva log resistivitas ternyata ada separasi maka dapat disimpulkan bahwa pada zona tersebut terjadi pengusiran dari posisinya oleh lumpur pemboran. adanya pengusiran merupakan indikasi awal pada zona tersebut bahwa pada zona tersebut memiliki porositas dan permeabilitas. Untuk zona yang terisi hidrokarbon pada umumnya ditunjukkan dengan nilai resistivitas yang tinggi dan untuk zona yang terisi air ditunjukkan dengan nilai resistivitas yang rendah, hal ini dikarenakan air bersifat konduktif dan minyak bersifat resistif. Pada reservoar karbonat nilai resistivitas yang tinggi belum tentu menunjukkan bahwa pada formasi tersebut terisi hidrokarbon dikarenakan batu gamping memiliki nilai resistivitas yang tinggi pula. karena itu hasil yang didapatkan dikombinasikan dengan data log densitas dan neutron.

Pada daerah yang terisi hidrokarbon kurva log densitas dan log neutron pada skala yang sama menunjukkan separasi positif. Hal ini dikarenakan hidrokarbon memiliki hydrogen index yang rendah sehingga ketika neutron tools menembakkan high energy neutron di dalam formasi. Pada daerah yang terisi dengan hidrokarbon menunjukkan nilai yang lebih rendah. Sebaliknya, untuk log densitas pada daerah yang terisi dengan hidrokabon akan menunjukkan nilai yang lebih tinggi. karena hal itu terjadi separasi positif pada daerah yang terisi dengan hidrokarbon. Untuk membedakan secara kualitatif tipe hidrokarbon yang mengisi formasi tersebut dilihat besarnya separasi positif antara $\log$ densitas dan $\log$ neutron, separasi log untuk gas lebih besar dari pada untuk minyak, karena hydrogen index pada gas lebih kecil.

Setelah diketahui litologi reservoar dan zona yang terisi minyak dan gas pada tiap sumur dengan cara analisis secara sepintas (quick look analysis) selanjutnya dilanjutkan dengan full analysis. Langkah awal yang dilakukan adalah menghitung porositas pada interval zona reservoar dengan menggunakan gabungan data log densitas dan porositas. Porositas dari densitas didapatkan dengan menggunakan Pers. 2 sedangkan untuk neutron langsung menunjukkan nilai porositas unit dengan skala batu gamping. Selanjutnya data porositas yang didapatkan dikoreksi dari pengaruh lempung dengan menggunakan Pers. 3 dan Pers. 4. Porositas effektif didapatkan dengan menggunakan Pers. 5. Volume shale didapatkan dengan menggunakan Pers. 1. Setelah dihitung nilai porositas pada zona yang terisi hidrokarbon pada tiap sumur selanjutnya dicari nilai resistivitas air (Rw) dengan menggunakan Pers. 7 pada tiap sumur dengan asumsi bahwa zona yang diambil adalah zona dengan saturasi air $100 \%$. Zona jenuh air diketahui dengan melihat respon dari log resistivitas dan separasi antara $\log$ densitas dan neutron. Pada zona jenuh air $\log$ resistivitas akan menunjukkan nilai yang rendah dibandingkan 
zona yang terisi hidrokarbon serta berhimpitnya atau separasi antara $\log$ densitas dan neutron sangatlah kecil. Langkah selanjutnya adalah menghitung nilai Sw pada tiap sumur dengan menggunakan Pers. 8 dengan parameter yang digunakan adalah $\mathrm{a}=1, \mathrm{~m}=2, \mathrm{n}=2$. Digunakannya persamaan Archie daripada persamaan Sw lainnya dikarenakan pada reservoar batuan karbonat pengaruh lempung tidak terlalu besar dibandingkan dengan reservoar pada batu pasir.

Selanjutnya dicari nilai permeabilitas dengan menggunakan persamaan Tixier dengan asumsi bahwa Swirr=Sw, dengan anggapan bahwa yang didapatkan adalah permeabilitas minimum pada zona tersebut. Setelah didapatkan nilai top struktur, porositas rata-rata tiap sumur, saturasi air rata-rata tiap sumur, dan tebal lapisan yang menghasilkan hidrokarbon (net pay) selanjutnya dibuat peta kontur dengan nilai-nilai yang didapatkan dari perhitungan sebelumnya.

Pada sumur ITS-25, ITS-28, ITS-29 terlihat bahwa ada beberapa data dengan densitas yang sangat rendah, dan setelah dikorelasikan dengan data cutting description, data tersebut merupakan batu bara (coal).

Dari hasil analisis data dan pembahasan didapatkan nilai porositas tertinggi pada sumur ITS-24 dengan nilai porositas $17,6 \%$, saturasi air terendah pada sumur ITS-05 dengan nilai 32,8\%, permeabilitas tertinggi pada sumur ITS-06 dengan nilai $90955,1 \mathrm{mD}$, dan tebal net pay tertinggi pada sumur ITS-06 dengan nilai 56 Meter. Dengan variasi nilai Rw dari 0.078 - 0.289 Ohm.meter. Pada peta kontur top struktur terlihat bahwa bentuk jebakan merupakan anticline. Karena tebal netpay berhubungan dengan peta kontur top struktur, maka berdasarkan peta kontur keseluruhan, dapat ditunjukkan bahwa pengembangan lapangan yang baik adalah pada arah Utara dan Timur Laut, yang ditunjukkan dengan ketebalan netpay yang lebih tinggi dibandingkan dengan arah lainnya. Selain tebal netpay, nilai saturasi air juga relatif rendah untuk arah utara dan timur laut dengan nilai porositas yang tidak terlalu jelek jika dibandingkan daerah sekitarnya.

\section{SIMPULAN}

Dari hasil analisis data dan pembahasan didapatkan nilai porositas tertinggi $17,57 \%$ pada sumur ITS-24, saturasi air terendah $32,84 \%$ pada sumur ITS-05, permeabilitas tertinggi $90955,1 \mathrm{mD}$ pada sumur ITS-06, dan tebal netpay tertinggi 56 meter pada sumur ITS-06.

\section{Ucapan Terima Kasih}

Penelitian ini merupakan kerjasama antara PT. Pertamina, Unit EP Regional Jawa dengan Laboratorium Geofisika Jurusan Fisika FMIPA ITS. Kami menyampaikan pengahrgaan yang stetinginya atas diskusi yang sangat bernas dari kolega dan sejawat para ahli kebumian terhadap hasil-hasil penelitian ini.
[1] Arpandi, D., Patmosukismo, S., The Cibulakan Formation as One of the Most Prospective Stratigraphic Units in the Northwest Java Basinal Area, IPA Proceeding, Vol 4th Annual Convention, Jakarta, 1975.

[2] Budiyani, S., Priambodo, D., Haksana, B.w., Sugianto,P., Konsep Eksplorasi Untuk Formasi Parigi di Cekungan Jawa Barat Utara, Makalah IAGI, Pertemuan Ilmiah Tahunan ke-20, Jakarta, 1991.

[3] Harsono Adi, Evaluasi Formasi dan Aplikasi Log, Edisi Revisi 8 Mei 1997, Shlumberger Oil Services, 1997.

[4] Koesoemadinata. R.P., Geologi Minyak dan Gas Bumi (Edisi kedua, Jilid 1 dan 2, Penerbit ITB, Bandung, 1980).
[5] Martodjojo, S., Evolusi Cekungan Bogor (Penerbit ITB, Bandung, 2003)

[6] Reynolds, J.M., An Introduction to Applied and Environmental Geophysics (Jhon Wiley \& Sons, 1997).

[7] Serra, 0., Sedimentary Environment from Wireline Logs (Imprimerie Louis Jean, Schlumberger, France, 1989).

[8] Schon, J.H, Physical Properties of Rock (Institute of Applied Geophysics Leoben, Austria, 1998).

[9] Tearpock, D.J., Bischke, R.E., Applied Subsurface Geological Mapping (Houston, USA, 1982). 


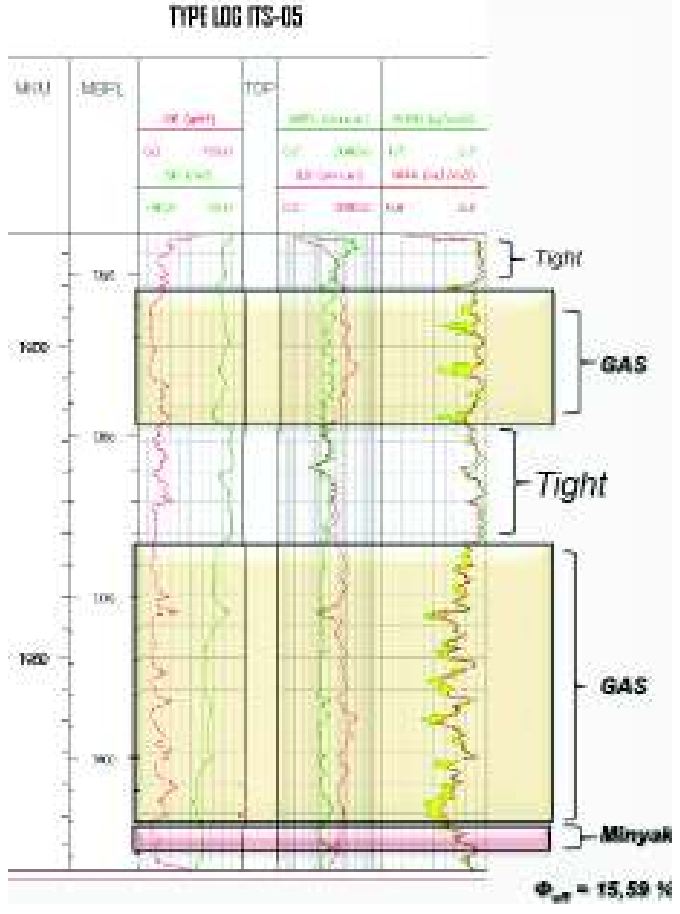

(a) Sumur ITS-05

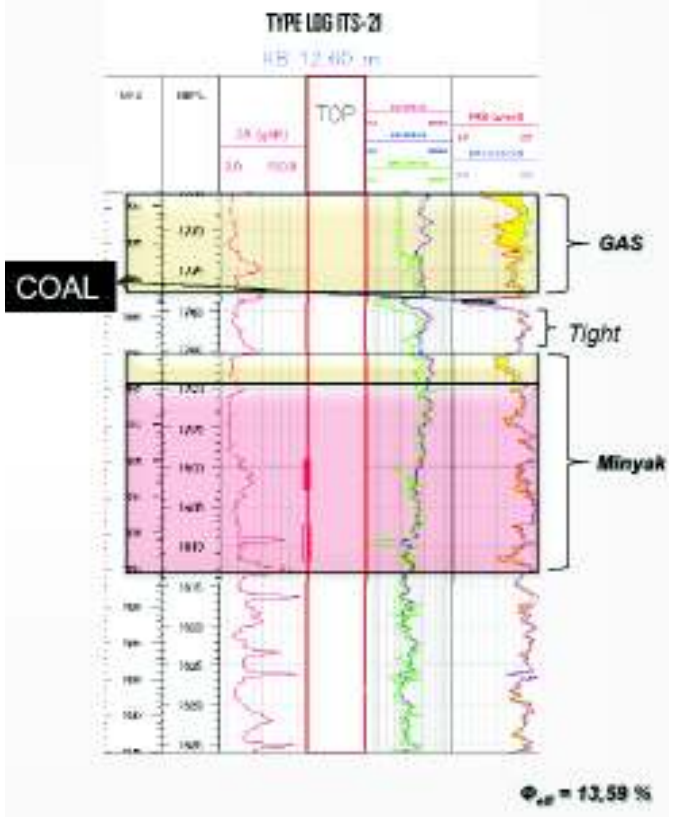

(c) Sumur ITS-21

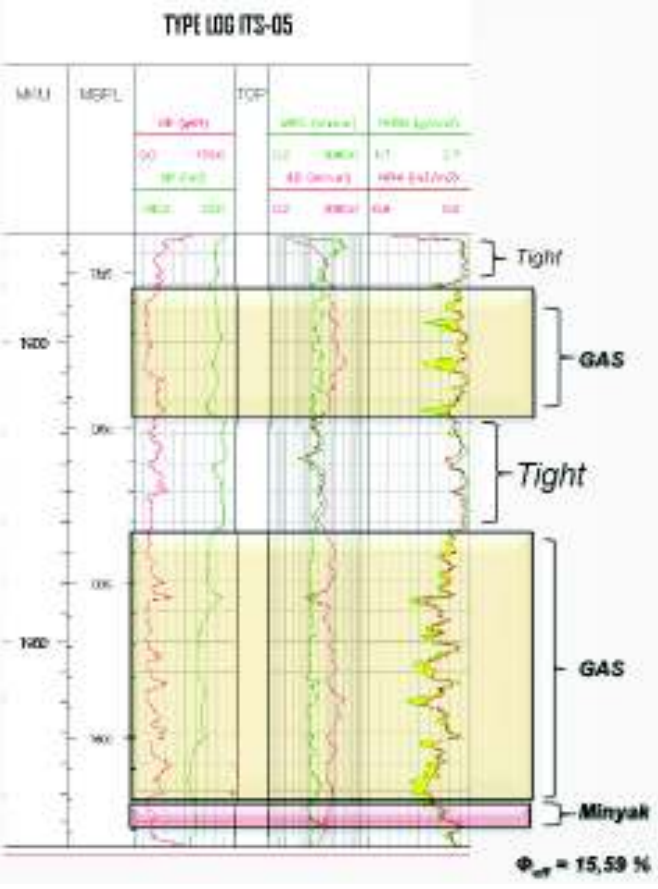

(b) Sumur ITS-06

Type $\log$ ITS-24

BF 1401 .

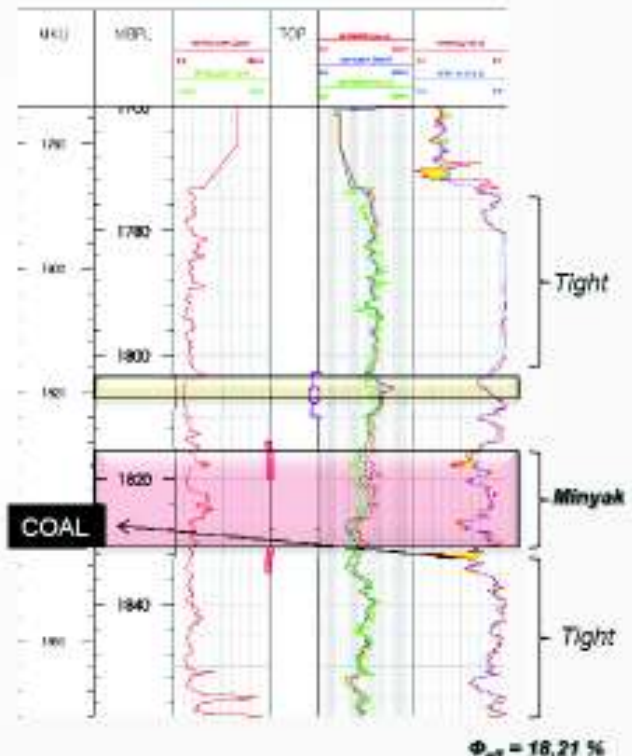

(d) Sumur ITS-24

Gambar 3: Hasil analisis log sumur ITS-05, ITS-06, ITS-21, dan ITS-24 


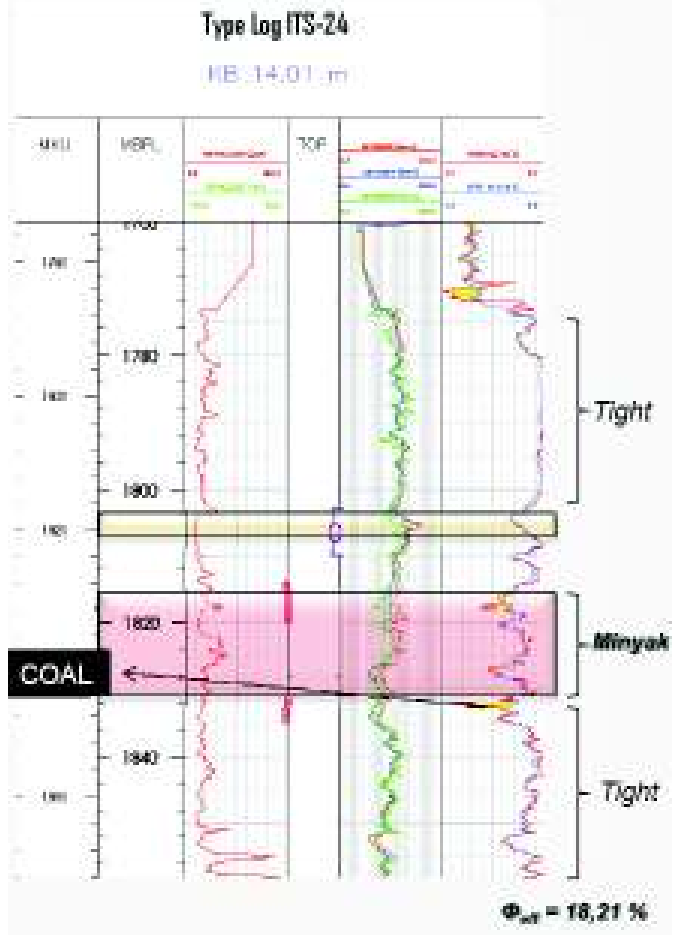

(a) Sumur ITS-25

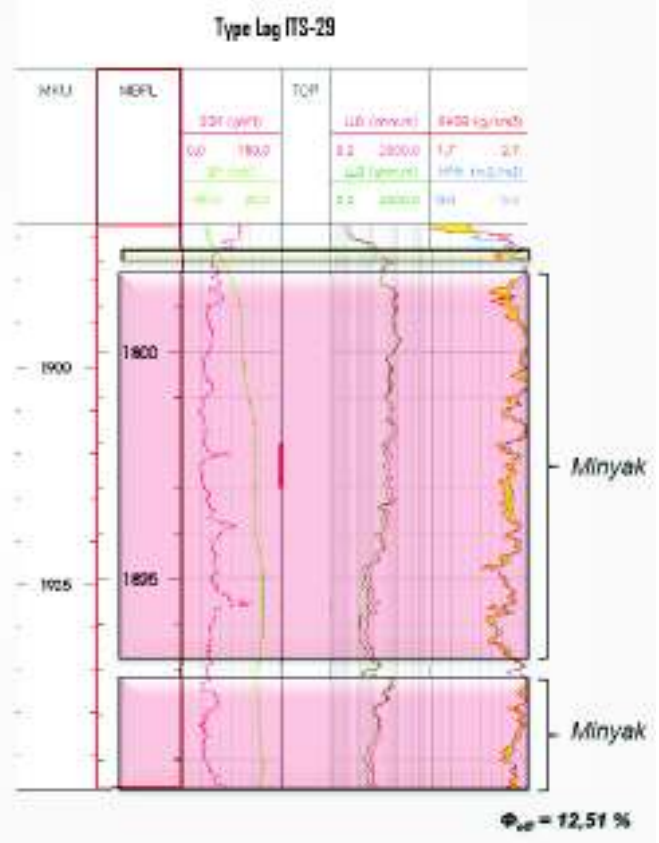

(c) Sumur ITS-28

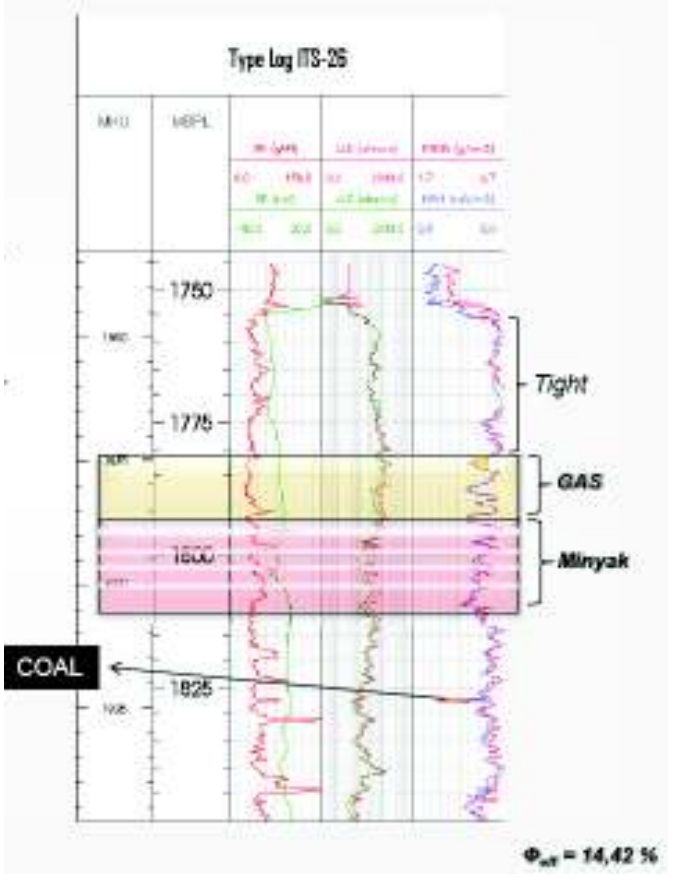

(b) Sumur ITS-26

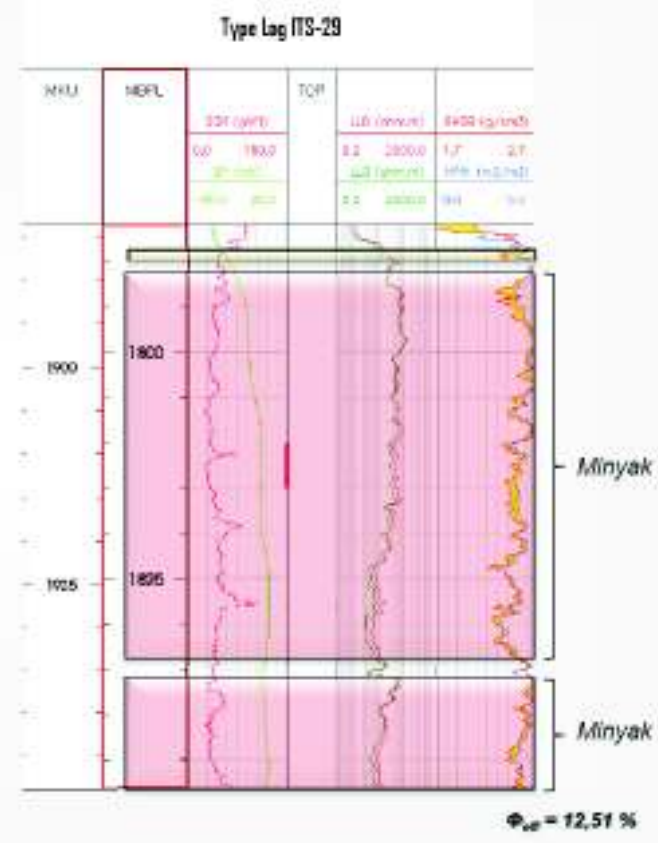

(d) Sumur ITS-29

Gambar 4: Hasil analisis log sumur ITS-25, ITS-26, ITS-28, dan ITS-29 


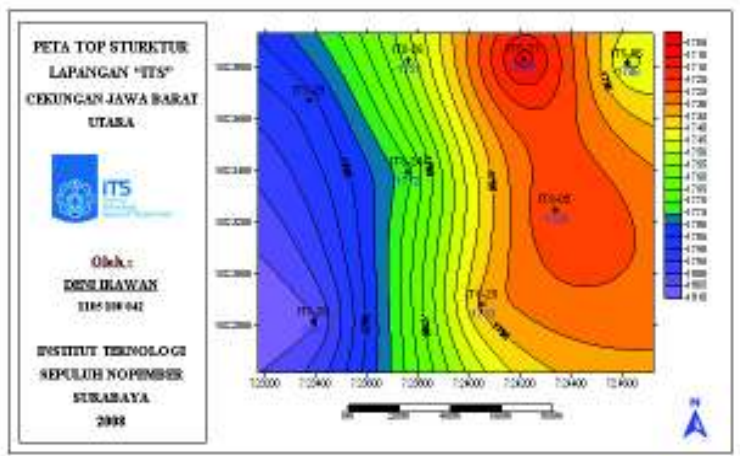

(a) Peta top struktur lapangan "ITS"

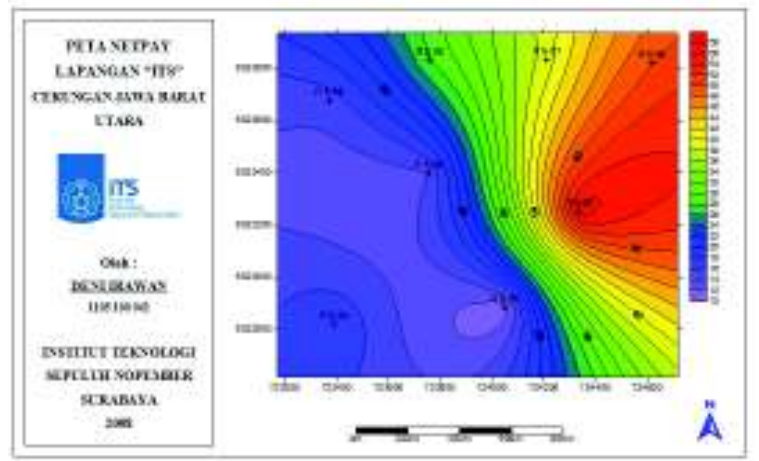

(c) Peta netpay lapangan "ITS"

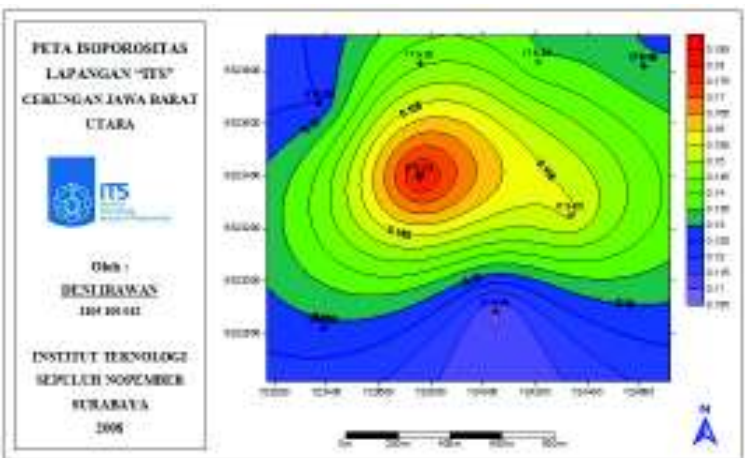

(b) Peta Isoporositas lapangan "ITS"

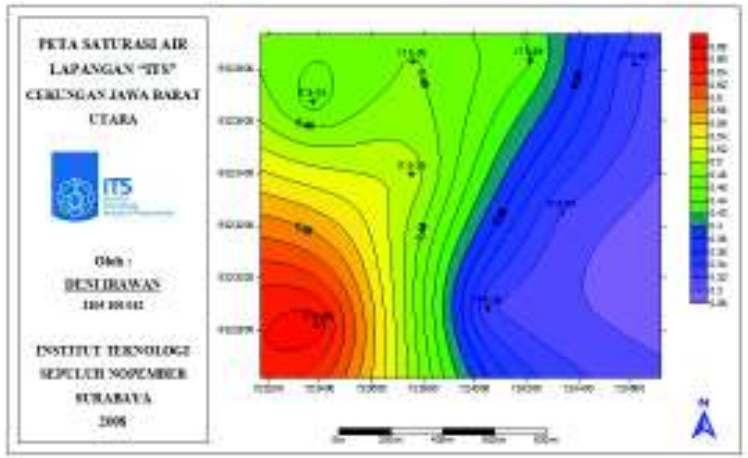

(d) Peta saturasi air lapangan "ITS"

Gambar 5: Peta top struktur, isoporositas, netpay dan saturasi air lapangan "ITS" 